\title{
Explication of Tacit Knowledge in Higher Education Institutional Research through the Criteria of Professional Practice Action Research Approach: A Focus Group Case Study at an Australian University
}

\author{
Edward Sek Wong \\ Universiti Tunku Abdul Rahman, Malaysia
}

edwardwong@graduate.uwa.edu.au

\begin{abstract}
This paper reports on critical and reflective practitioner heuristic inquiries that investigated a focus group case study of doctoral candidates concerning the adoption and use of the Knowledge Management Processes available to them at an Australian University. In addition, this paper also investigated some research processes of current professional and academic practices. Of particular interest was the conversion of the group's and the individual's tacit knowledge into explicit knowledge within the organizational domains, personal domains, or both. This paper brings out inner dialogues and open discourse responses in one-on-one interviews within a phenomenological, reflective practitioner methodology, in order to explain the increased interest in this methodology within the nature of Critical Institutional Research. One area of controversy between Critical Institutional Professional Research and the traditional Institutional Professional Research is the role of "reflective practice," which remains under-developed. This paper explores the importance of reflective practice employing the term "living thesis paradigm" as a means of developing expert research methods. Finally the conclusions aim to help the individual practitioner develop skills of reflective practice and to help organizational members develop communities of inquiry, as well as to contribute to wider understanding of the place of inquiry in the development of professional practice.
\end{abstract}

Keywords: Action Research, Higher Education Knowledge Management, Reflective Practice, and Institutional Professional Research.

\section{Introduction}

Material published as part of this publication, either on-line or in print, is copyrighted by the Informing Science Institute. Permission to make digital or paper copy of part or all of these works for personal or classroom use is granted without fee provided that the copies are not made or distributed for profit or commercial advantage AND that copies 1) bear this notice in full and 2) give the full citation on the first page. It is permissible to abstract these works so long as credit is given. To copy in all other cases or to republish or to post on a server or to redistribute to lists requires specific permission and payment of a fee. Contact Publisher@InformingScience.org to request redistribution permission.
This paper examines the role of employing reflective professional practice action research as an approach in the evaluation of the explication of tacit knowledge. The paper also presents an account of personal experiences as a heuristically critical reflective practitioner while acting as a knowledge management consultant. Moreover, personal experiences as an academic faculty member and researcher are indicated. 
Moreover, this paper discusses the roles of developing reflective skills and the processes employed in conducting Critical Institutional Professional Research (CIPR). In recent years there has been an increase interest in the nature of CIPR research and the development of methodologies to explore this subject (Peterson, 2000). One area of controversy between CIPR research and the traditional Institutional Professional Research (IPR) research is the role of 'reflective practice,' which remains under-developed (Light \& Cox, 2001). In this paper, the importance of reflective practice employing the term 'living thesis paradigm' as a means of developing expert research methods is explored.

The first section of this paper introduces the literature of reflective practice, which argues for the validity of a reflective practice inquiry and involves the using of the living thesis paradigm inquiry. The living thesis paradigm inquiry involves a heuristic autobiographical self-study with a reflexively phenomenological approach influenced by an analytical psychology and uses a writing style influenced by postmodern perspectives. In this paradigm inquiry, the emphasis is on conducting in-depth and wide ranging reflection of the empirical material in order to collect heuristic impressions, or insights, or both that have an effect upon the authors' personal relationships and relationships with all involved in conducting the research. Through the stages of this paradigm inquiry, deep understandings are sought that can illuminate the situation, thus providing meaningful communication and inspiring appropriate actions (Wong, 2003a). This is followed by descriptions and a justification for a reflective practitioner's writing style. The second section discusses the research methodology used here, and the third section discusses the focus group case study of doctoral candidates employing the living thesis paradigm within reflective practices in investigating the explication of tacit knowledge. The last section of this paper identifies areas for future research.

\section{What is a Reflective Practitioner?}

Schön (1983) and Moon (2000) described a reflective practitioner as someone who is simply thoughtful about his or her own practice. From this notion, they indicated that reflective practice involves the mental process of reflecting, which may or may not be characterized by what is called 'being reflective.' They also considered a reflective practitioner as a person who has a selfimage as a facilitator, where there is an important recognition of the uncertainties within a profession. Moreover, they considered a reflective practitioner as someone who has the necessary active professional knowledge, coupled with an awareness of the professional problems requiring resolution within their actual professional business practice. This reflective practitioner copes with these problems by putting the client-advisor relationship at the center of their business practice. This is an attempt to develop shared reflective negotiated meanings and understandings as a joint business process with their clients. A person with a self-image as a facilitator, recognizing the uncertainty within a profession, has the knowledge base of a member of his/her profession and is aware of the problems that need to be resolved in any professional practice. To succeed the reflective practitioner deals with this uncertainty by putting client relationships at the centre of his/her professional practices with attempts to develop negotiated shared meanings and understandings as a joint process, all of which require reflection.

Moon (2000) supported by Schön (1983) and Proctor (1993) offer a similar view by stating that reflective practice is the process of looking back in a critical way at what has occurred and then using the results of this process, together with professional knowledge (with technical and ethical aspects), to tackle new situations. Smyth (1989) noted that critical elements have been widely associated with the reflective practice method and are often taken to be the main purpose of reflection. In similar vein to Smyth's ideology, Wong and Williams (2002) expressed that in a reflective professional education, the activities of teaching often need to be set in their historical, political, theoretical, and moral context, as not considering them turns reflective teaching into a 
technical process. From this, reflection is the "active and militant" tool that enables that contextualization (Smyth, 1989, p. 3), and, in this regard, the "technical-rational" education fails to provide the elements necessary to enable the doctoral students to develop the heuristics needed to deal with the unpredictability and chaos of real world issues.

Wong and Williams (2002) also supported the notion that professional practice action research and reflective practitioner research are usually written in distinctive reflective practitioner styles, as individuals evolving as action researchers find their own voice and distinctive authorial style. Dewey (1933) appeared to write about the function of reflective thought in learning from experience first, and alluded to this writing concept within reflective practices. Dewey further showed that a researcher's notes, reflections, and insights are integrated with the empirical data from interviews with colleagues, supervisors, mentors, and clients; this approach is supported by Friedman, Lipshitz, and Overmeer (2001). This evolution is also shown in the writing style used by Schön $(1983,1987)$. Schön's writing style involves one's work experience through the lens of one's insight and generally requires some degree of emotional and insightful perceptions. This research method allows a researcher to give an account of the application of workplace knowledge, as it encourages the research participants to reflect on their experiences and then to comment on what they believed they have learned from those experiences (Williams, 2000a, 2001; Wong \& Williams, 2002).

\section{Reflective Professional Practitioner Action Research Approach: The Ontological Perspective}

This paper describes the consensus among institutional professional research cultures, teaching, and learning, using these proposed new taxonomies to yield a new approach - reflective practitioner action research. This approach takes these taxonomies into account attempting to explain the how and why problems are resolved in a particular way in a given culture at a given time. The approaches and philosophies of Habermas (1984) and Wieman (1963), as well as Nonaka and Takeuchi (1995), are within the approach and methodology of Action Research. These approaches are the sources used to explicate the studied situation proposed by this paper.

The use of human experiences as sources and resources is the foundation of heuristic enquiry (Moustakas, 1990). These forms of inquiry begin the processes of understanding a topic, as well as finding its essences and meanings. However, such type of research requires a greater intensity of investigation than is usually the case in order to establish a quality based result founded upon a given set of experiences (Moustakas, 1990). This personalized approach establishes the necessary research factor of rigor, but not that of duplication, because through insights, reflections, and mutual experiential explanations, these research components are unique for a time and place, a situation that prevents duplication.

What is the value of a single researcher's or participant's contribution? This work advocates that the value is found within a contributor's ability to vent his or her emotions concerning the topic, which when examined, considered, and then responded to, either with additional emotions or dispassionately, this value is able to peel back another layer of obstructing literature debris. This leads researchers nearer to the apparently impossible - a subjectively supported objective truth. In a situation of diverse institutional research cultures, emotions seem always to play a supportive but vital role in any discussion, and, in a heuristic enquiry, these must be evaluated as well as any apparent 'facts' presented to the primary researcher. This is the major strength of Action Research - the range of data is great but evaluative and, with an ever decreasing spiral of revealing supportive data, the generated warranted assertions and conclusions tend to be self-evident, as well as logical, founded upon this reducing data spiral (Whitehead, 2002; Wong \& Williams, 2002). 
This reflective practice data spiral, from the general to the specific, refers to our fundamental selfidentity, which lies in one's relationship with his/her own spirit. This reflexive-reflection process can also open the door to self-awareness and self-discovery. If individuals were not reflecting upon the research topic at the time or were not accessible to aid in the advance of the research project, then the project must partially fail, particularly for those 'missing' individuals. Meditation, self-reflection of one's own thoughts, and listening to others are known ways to enrich one's consciousness and gain important insights into who as well as what an individual is, irrespective of the research project concerned.

\section{Creating the Living Thesis Paradigm: The Epistemological Perspective}

The developments in what Whitehead (1993) termed the "living thesis paradigm" (p. 69) at the Perth Centre of Reflective Practitioner Research Group (Wong \& Williams, 2002) and at the University of Bath's Centre for Action Research Professional Practice (Reason, 1999; Whitehead 1998, 2002) are effective here. Whitehead's term of living thesis paradigm can be constructed from practitioner's enquiries of the kind, "How do I improve my practice?" Whitehead argued that researcher-participant dialogues are a new way in which action researchers can represent living theories about practice. Additionally, he noted that this approach celebrates a living form of practitioner educational theory that is open-ended and contains an intention to create something better (Wong, 2003a). Whitehead (1998) asserted that including the "I" and embracing subjectivity is essential to research within this paradigm. Furthermore, Whitehead (2002) exhorted individuals to not be silent, or hold back their perspective, or try to struggle dishonestly in order to fit their private world with their public face through the process of denying or by inauthentically conforming to oppressive domination concerning gender, race, or differently cultured selves. This, he noted, allows a researcher to engage in research wanderlust, within their research interest, altering research problems and research questions when necessary, in order to discover new research avenues without the necessity of entertaining what is sometimes called 'political correctness.' The living thesis paradigm compels an author to document, as part of their research, any conflicts he or she experiences. When the values that a researcher holds internally are not reflected in the way her or she behaves externally, the satisfaction a researcher feels when his or her values and actions are in harmony does not exist; as well, there is a serious cost to the researcher and possibly to his or her research. Whitehead $(1993,1996)$ commented that one's espoused theory ideally should be consistent with one's lived theory. Whitehead further argued that living theory refers to the explanations that are not embodied in the individual's life forces, as this theory proposes an intention to create something in the future based on a person's goals or values. Additionally, these events are directed within a researcher's personal action plan. This paradigm is an attempted explanation challenging any researcher to make sense of the present in terms of evaluations of the past, leading to an improvement in their professional environment (Wong, 2003b). This theory is an explanation that makes sense of the present in terms of an evaluation of the past with an intention to change some aspect of one's own practice or of the world in the future.

\section{Writing Style}

Denzin and Lincoln (1994, p. 502) suggested that academic research writing can tend towards one of five major paradigms:

1. Positivists styles: tightly spare and non-personal with phrases such as variables, experimental design, subjects, statistical significance, triangulated;

2. Constructivist styles: more descriptive and commonly including words like emergent, prior knowledge, culture, and participants; 
3. Critical styles: with politically inclined terms such as empowerment, society, power, and ethics;

4. Interpretive or phenomenological styles: subjectively descriptive and sometimes allusive with common phrases such as personally constructed realities, cultural perspectives, interpretive knowledge, intersubjectivity, reflective, discourse;

5. Feminist styles: descriptively suggestive and aware of cultural conditioning using terms like gender, equity, and reflexivity.

Here is clarified the writing style of this style of paper as an inquiry including the "I" that is not in principle governed by pre-established rules. This was a deliberate attempt to place this research in a setting where participative, collaborative, action-oriented, critical, heuristic, and reflective phenomenological forms of inquiry can be fostered (Lyotard, 1986; Wong, 2003a). This writing style approach allows a researcher to give an account of how this researcher applied knowledge in his or her workplaces and professional offices. As well, this method encourages reflection upon their experiences and then addition of comments on what they believe they have learned from those experiences (Williams, 2000b, 2001; Wong \& Williams, 2002). The use of the first person "I" in some research writing is not recommended, while in Action Research it is almost a trademark of this paradigm.

As discussed in the following section, this style of inquiry allows for many important dimensions of research, not only formal communication, but also personal accounts within Whitehead's (2002) Living Thesis Paradigm. This paradigm can emerge as a part of historical-political dilemmas and actions, feelings and emotional intelligence, aesthetic allusiveness, questions of justice and truth, ethical imperatives, faith dimensions of people's lives, and even the unconscious wellsprings whence come intuitions and urges and dreams and visions (Wong, 2003a).

\section{Research Methodology}

This study involves research, teaching, and learning contexts in higher education with human science hermeneutical dimensions. That is the process of mimetics through reconstructions of facts by the understanding of their meanings and intentions rather than by deductive explanation (Standing \& Benson, 2001; Wong, 2003b). Moreover, this work suggests that an ethnographic reflection on professional practitioner focus group case study methodology is appropriate. This research investigated one focus group in depth, the doctoral candidates at an Australian university, in an attempt to gain empirical and interpretive understanding of their conclusions in terms of their conversion of tacit knowledge to explicit knowledge and of their adoption of the Knowledge Management Processes in higher education.

The flow chart indicated in Figure 1 represents the ethnographic reflection of the professional practitioner case study methodology used in this study. In the first phase, the philosophical perspective, either the interpretivist, the positivist, or both, influences the methodology. The ethnographic-reflective-practitioner-practice paradigm employing critical social theory narrows the interpretive approach. Within the first stage is the use of qualitative ethnographic reflection adopting a critical social theory perspective. In the second phase, the selection of research instruments that includes both face-to-face interviews and documentation is outlined. This is followed by the establishment of data collection procedures that takes place through the recall of the reflective practitioner data. Then the application of the hermeneutic approach is used on the interpretation of interview transcripts. In the third phase, the analyses of data using an ethnographic interpretative approach through a data meta-matrix are completed. The processes of discovery, observation, documentation, and assessment are integral aspects of the methods employed in this latter stage of the study. Then, a presentation of the recorded summaries and interpreted findings that includes the reflections of the reflective practitioner is completed (Wong, 2003b). Figure 1 illus- 
trates the methodology flow chart showing the progression of the research. It also demonstrates the problems of combining critical social theory with a reflective phenomenological approach.

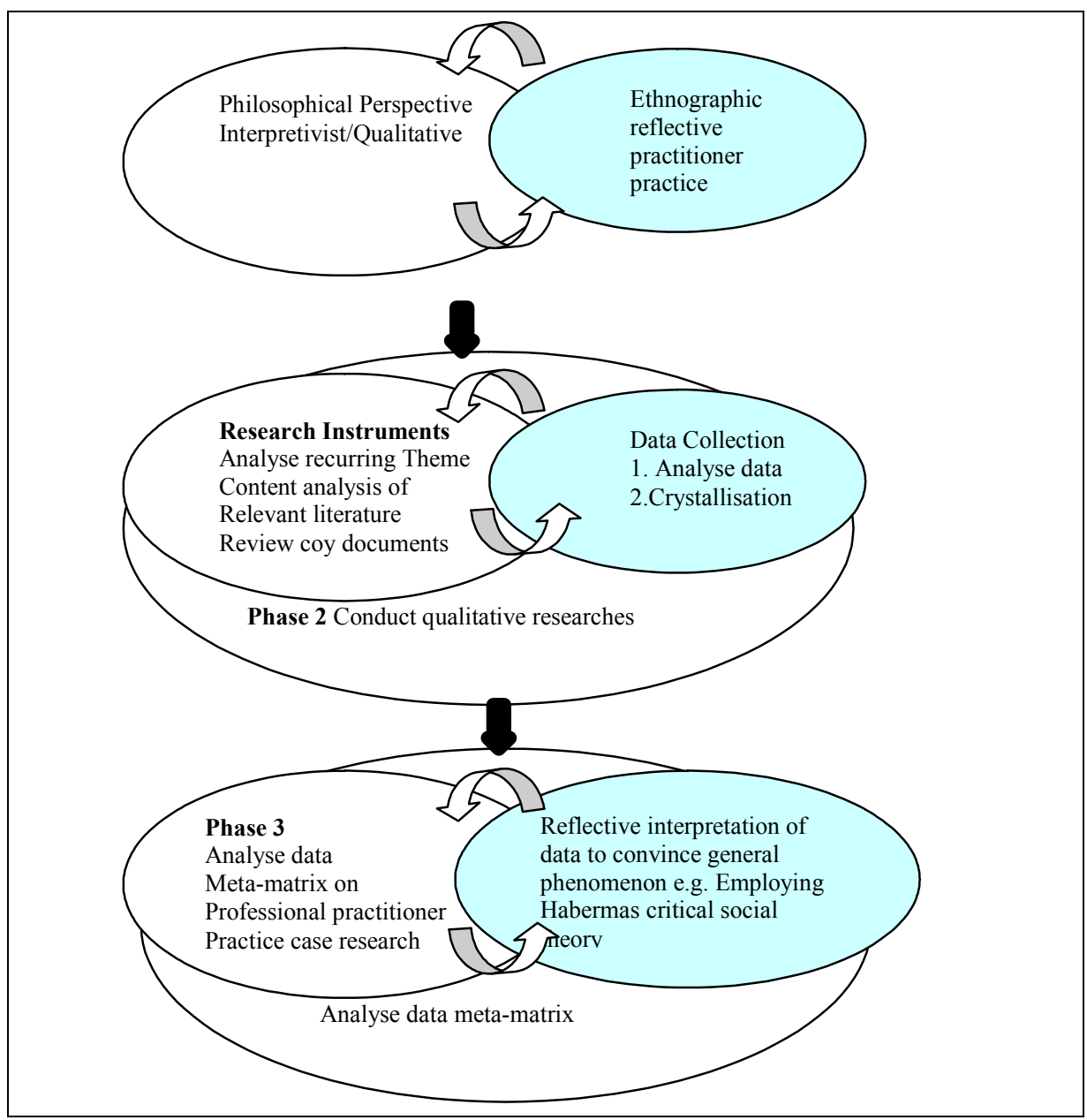

Figure 1: Flowchart of the reflective practices methodology

Habermas (1987) pointed out that "any methodology that systematically neglects the interpretive schemata through which social action is itself mediated is doomed to failure" (p. 341). Habermas also demanded that the "grasping of 'meaning' that is constitutive of social reality" (p. 341). Hence the qualitative nature of this type of research approach is only enhanced by "experiential accounts or lived-experience descriptions [which] are never identical to lived experience itself..." (p. 342). In similar vein with Habermas' concepts, Van Manen (2000, p. 2) said:

...all recollections of experiences, reflections on experiences, descriptions of experiences, taped interviews about experiences, or transcribed conversations about experiences are already transformations of those experiences. The upshot is that we need to find access to life's living dimensions while hoping that the meanings we bring to the surface from the depths of life's oceans have not entirely lost some the natural quiver of their undisturbed existence.

Focus group case study research allows cross-case analyses and comparisons and the investigation of particular phenomena in diverse settings (Yin, 1994, p. 46). However, as the adoption of knowledge management process systems, particularly in Australia, are still in the emergent phase, it was felt that, in this instance, case research methodology would be most appropriate, as case study research is best utilized when the goals of a researcher and the nature of the research topic 
influence the selection of a strategy. Supporting this action, focus group case research is particularly appropriate for certain types of problems, such as those in which research and theory are in the early, formative stages (Yin, 1994, p. 47).

\section{Research Objectives}

The literature noted above provides a brief overview of the ontological and epistemological context pertaining to action and reflective practitioner research. The aim of this research was to develop a model of explicating tacit knowledge by employing ethnographic research methodology. Under this approach, the primary researcher should be a member of the work group or culture being researched, as this allows personal consideration of a researcher's responses, thoughts, and experiences to be as important as any of the participant's and should be included in the empirical data and analysis (Williams, 2000a, 2001;Wong, 2003a). From this, a researcher can glean warranted assertions sourced from his or her own lived experience as well as from the experience of others in the study (Williams, 2000a; Wong, 2003b).

\section{Case Scenario}

University A is an Australian university. It is one of the main universities in Australia with a total of approximately 15,000 students sourced locally and from overseas. University A also offers a broad range of degree programs from undergraduate through to doctoral candidature and postdoctoral fellowships.

\section{Analysis Framework: A Case Study of an Australian University}

This study discusses a workshop concerned with an investigation into the adoption of a Knowledge Management Process System considered appropriate for a reflective practice approach, where these reflective practices may lead to a development of a subject expertise within the International Professional Research model. The model in Figure 2 sets out the processing order where a heuristically critical reflective practitioner approach was achieved using the principles of action research realignments to augment the principal researcher's ethnographic experience of being professionally involved in the development of knowledge sharing through a Knowledge Management Process System.

The methodology chosen for this pilot study was qualitative in nature, and the resulting information is a compilation of discussions and debates surrounding the issues of knowledge sharing (tacit knowledge) through the use of a Knowledge Management Process System within University A. The comments were from structured workshop settings designed to achieve specific outcomes for this paper, and the analysis was based on systematic content coding (Morgan, 1998). It also utilized a participant approach, which relies on interviewee quotations to illustrate themes and support key findings (Glesne \& Peshkin, 1992). As the following section illustrates, the pilot study investigated the possibilities of explicating tacit knowledge by employing the developed models (see Figures 1 and 2). Six doctoral candidates were formed into two focus groups (Group $\mathrm{AA}$ and $\mathrm{BB}$ ) and asked to consider how they, and perhaps others, might react to the interview questions. 


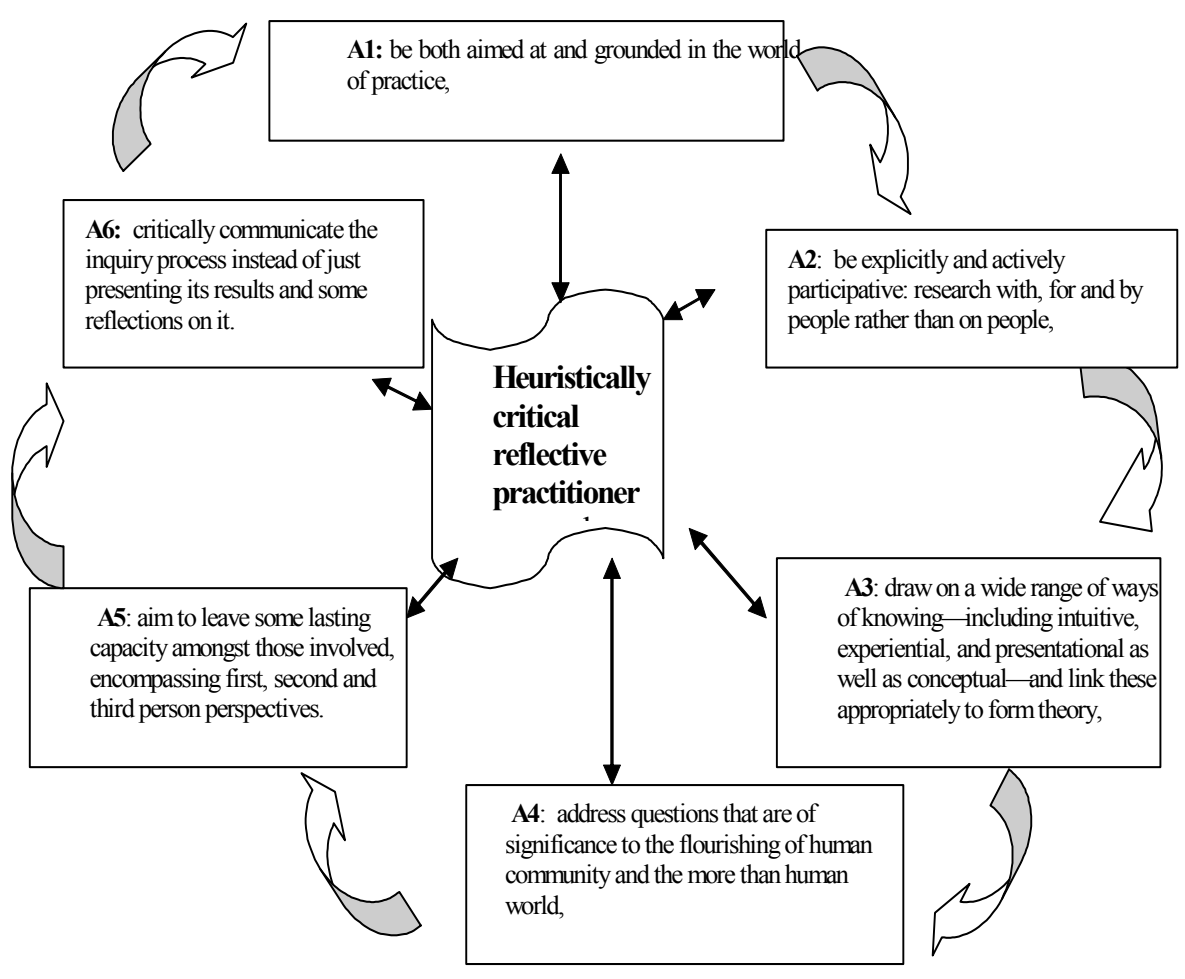

Figure 2: Flowchart of the heuristically critical reflective practitioner approach (Reason \& Bradbury, 2001)

\section{Results and Discussion}

\section{Analysis based upon action research criteria list}

Figure 3 profiles the respondents and the ratings of the responses to the interpreting quotes from the interviews based upon the Action Research criteria located in the appendix. Ranks were determined on the basis of a 5-point Likert scale, where (5) is 'strongly agreed' with the provision that the respondents were asked to rank (5) if their perceptions were considered the most effective, through to (1) 'strongly disagree', if perceptions were considered least effective.

Participant responses, which were sourced from semi-structured, unstructured, or dialogical situations, were written down, verified, and then critiqued and all of this became key empirical data. These data were then placed into a context under the terms of 'bouncing theory' (Column 1), this related these quotes to research themes, cases, philosophy, or approaches (Column 4). These quotes were then analyzed with regard to the Informing Theory of Reflexive Verisimilitude, or an appearance of truth (Column 3). 


\begin{tabular}{|c|c|c|c|c|}
\hline & Column 1 & Column 2 & Column 3 & Column 4 \\
\hline Participants & $\begin{array}{l}\text { Bouncing } \\
\text { Theory }\end{array}$ & $\begin{array}{l}\text { Action } \\
\text { Research Crite- } \\
\text { ria list (From } \\
\text { Figure 2) }\end{array}$ & $\begin{array}{l}\text { Reflexive verisimili- } \\
\text { tude (appearance of } \\
\text { truth) }\end{array}$ & $\begin{array}{l}\text { Cases/ } \\
\text { Philosophy/ } \\
\text { Approach }\end{array}$ \\
\hline $\begin{array}{l}\text { For example, } \\
\text { Group AA } \\
\text { responses }\end{array}$ & $\begin{array}{l}\text { 1.McClane } \\
\text { and Mento } \\
(1991), \\
2 . \\
\text { Fitzsimmons } \\
\text { (2000) }\end{array}$ & $\begin{array}{l}\text { A1, A2, A3, } \\
\text { A4, A5 } \\
\text { ('Strongly } \\
\text { Agree') } \\
\text { AR1, AR4, } \\
\text { AR6, AR8, } \\
\text { AR9, AR10 } \\
\text { ('Strongly } \\
\text { Agree') }\end{array}$ & $\begin{array}{l}\text { 1. Habermas (1997) } \\
\text { context of lifeworlds } \\
\text { 2. People lifeworlds } \\
\text { concerns as manage- } \\
\text { ment issues. }\end{array}$ & $\begin{array}{l}\text { The philosophy } \\
\text { of } \\
\text { 1. Zimmerman } \\
\text { (1999) } \\
\text { 2. Kanter } \\
\text { (2000) }\end{array}$ \\
\hline
\end{tabular}

Figure 3: Respondents profile

The following section describes and analyses all the research interviews conducted with the given focus group participants at University A. (See Figures 4 and 5)

Question posed to participants: What are the roles of 'Knowledge Management Process Systems' knowledge repositories in supporting knowledge sharing through the processes of explicating tacit knowledge in your research area? What is your opinion of the proposition that "knowledge equals power" in the context of the political infrastructure of your organization?

Response from Focus Group AA: Initially we all have to define our core skills and knowledge for our professional services. As doctoral candidates and researchers, we know that knowledge relating to our skills, experiences, and the art of conducting research is valuable, but this tacit knowledge is all stored in the heads of the best-informed and experienced researchers. The transformation of some parts of this tacit knowledge to explicit knowledge is necessary and through Knowledge Management Process Systems we are able to see that such a task is possible, and we have seen that organizational knowledge can also be proactively managed. Our new Forum of knowledge repositories achieved a modest but noticeable participation growth and without the Knowledge Management Process Systems Forum, University A's capacity to encourage collaboration among all knowledgeable staff would be seriously restricted. We also noticed that these highly knowledgeable and skilled individuals also hold high level management positions and perhaps this because of their personal store of tacit knowledge, which they jealously clutch.

\section{From the Reflexive Practitioner:}

In the above quote, focus Group AA describes the way that the creation and use of University A's ICT (a knowledge management process system) knowledge repositories explicated tacit knowledge within the research area. Their point that the most experienced researchers are also the best-informed people appears to be consistent with McClane and Mento (1991) and Fitzsimmons (2000). They had found that by converting tacit knowledge into explicit knowledge this would enable an individual to learn and acquire the needed data and information, resulting in an increase in their personal knowledge. Furthermore, they suggested that knowledge is real and usable power and argued that management and interest groups controlling information indirectly control this power.

Focus Group AA's last sentence supports the assertion that Knowledge Management Process Systems repositories support collaboration within the process of explicating tacit knowledge, and this signal statement describes the need and the source of processes for the conversion of tacit knowledge and that it be proactively managed, akin to the phi- 
losophy of Zimmerman (1999) and Kanter (2000), who argued that control of information is seen as crucial to the sustainability of management structures within an organization, and so, embedding management ideology into knowledge and information to achieve ulterior intentions, both personal and corporate, are frequent organizational practices (Personal reflection).

\section{From the Action-researcher (to add other authenticating perspective):}

In the above reflexive verisimilitude (appearance of truth), the voice of the focus Group AA captured the vital qualities of Habermas' context of lifeworlds, as in his view the lifeworld's concerns of the people who are the best-informed are also management issues, as these issues created a compromise between administrative managers (who had managerial control and power) and the research staff within the laboratory. The perceptions of the focus Group AA were that they should secure some form of representative positions in the head office when involved in making decisions regarding the type of research and research budget issues. Focus Group AA realized that the key to such resources lay within the hands and bargaining skills of the best-informed people in their organization. The Knowledge Management Process Systems Forum (part of University A ICT) has demonstrated to all workshop staff ways to increase their knowledge and to use this knowledge to the advantage of their employer and, mostly, themselves; this is an opportunity that was unlikely just a few years ago.

Figure 4: Focus group respondents profile one

Question posed to participants: To what extent can organizational change resulting from the conversion of tacit knowledge to explicit knowledge through Knowledge Management Process Systems be effected through interaction that promotes openness and allows for the possibility of serendipity?

Response from Focus Group BB: For example, when our university reconsidered its strategies of funding sources for new projects and the types of research to undertake, the adoption of new strategies in relation to research projects stretched our previous established goals. The new strategies meant that by having all decisions made by the administrative headquarter staff by using teams from different faculties and all having common budget constraints, coupled with the linking of individual performance to research output success, and then establishing a "platform team" bringing together researchers, academic staff, and administration to identify new research projects, created a new set of problems. The new process involved the details of these activities, and the steps in coordinating the tasks involved were clearly distinguished by using an electronic interactive format, such as an e-mail distribution list, promoting a community awareness of the research agenda. Initially, there was a team of senior research staff who felt that there was a level of competition among certain individuals that worked against the sharing of knowledge and then we discovered that the interactive format of these Knowledge Management Process Systems assisted in overcoming these man-made barriers. Knowledge Management Process Systems not only influenced the organizational culture but also encouraged the gaining of further knowledge by colleagues and the encouragement of mutual trust or more positive signs indicating effective group work. All of this promoted openness and the development of a workable approach system for improving our work through wider exposure and broadcasting through online interactions and this provided space for serendipitous events. 


\section{From the Reflexive Practitioner:}

Focus Group BB states that organizational changes resulting from the conversion of tacit knowledge to explicit knowledge by means of University A's ICT (a knowledge management system) can be affected through an interactive format. They further suggest that University A's ICT facilitates and fosters the sharing of knowledge on a widespread scale. This study notes that radical changes affecting organizational culture involve organizing regular meetings and stimulating cross-faculty academic dialogue. Focus Group BB's contribution supports the assertion that an interactive format design promotes openness and allows for possible serendipity (Personal reflection).

\section{From the Action-researcher (to add other authenticating perspective):}

Focus Group BB has crystallized their perspective by using Habermas' Critical Social Theory where this group reflects upon matters concerning their lived experiences in dealing with serendipitous situations as these serendipitous actions form an integral part of their learning actions.

\section{Reflections on the above Theme.}

As a reflective practitioner, this study can now reveal and explore his interpretation and use of Habermas' theory of communicative action in providing a framework for analyzing the changes within the social-cultural contexts of knowledge management practice (Ngwenyama \& Lee, 1997). Habermas' theory of communicative action provides a fruitful framework for practitioners to understand human behavior, in particular, one that is oriented to the attainment of rational thinking. This human activity allows a sustaining knowledge sharing culture within an organization and uses a new knowledge sharing culture that is more meaningful as a person using communicative actions attempts to understand and give meaning to actions within the given situation, as this involves intersubjective and cooperative reflexivity (Ngwenyama \& Lee, 1997, p. 150). In doing so, this process allows individuals to express their personal voice, perspectives, and interpretations on how they employ their experiences through personal demonstrations within their day to day work in adopting the new Knowledge Management Process System.

In addition, this study views communication as an emotional as well as an intellectual act and from this, communicative action involves not only understanding what the speaker or writer means, but also how well a person recreates the intended meaning of the communication. In the light of this, it is important to understand how the sharing of tacit knowledge evolved and developed as new knowledge was interpreted, questioned, constrained, and used in various social-cultural contexts.

\section{Figure 5: Focus group respondents profile two}

In the above section, a discussion is presented on a range of strategies in regard to the sharing and managing of University A's tacit knowledge. Also, under the section of Reflexive Practitioner and Action-researcher, it is intended to facilitate and assist the reader in having a deeper understanding of the development, activities, and pertinent issues revealing the epistemology and practice in a narrative fashion that contains elements of a confessional ethnography (Van Manen, 1995, p. 8).

The above dialogues underpin the epistemological issues and assumptions that highlight the professional practices of University A's doctoral students in adopting the role of knowledge facilitators. In this light, the manifestation of a lived research setting experience is revealed through the participant's dialogues from University A, with the researcher and the reflexive practitioner, ac- 
companied by the voice of his own psyche (at times representing in Jungian terms, the innate wisdom of the anima) referred to as the action-researcher (Wong, 2003a).

Each voice in the above text box expresses a personal perspective and interpretation of the research action. In this writing, the researcher, through this study, believes that he may be able to capture the important qualities of the lived research experience as well as a sense of the appearance of truth. Discovering a meaning and its appearance by means of dynamic question and answer dialogues with my readers creates this emergence. The voices of the participants from University A are interspersed throughout the dialogue to help to create a sense of authenticity. Occasionally, hearing the voice of the author's own psyche (as action-researcher) adds other authenticating issues to the research findings (Wong, 2003a).

\section{Conclusion}

This study exposed the development of Whitehead's 'living thesis paradigm' theory (Whitehead, 2002), through a multi-voice dialogue about the life-world of this focus group of doctoral candidates from University A, primarily as a journeying practitioner researcher, as the researcher through this study, describes his 'big picture' view of managing organizational tacit knowledge through the adoption of Knowledge Management Process Systems.

The methodology section outlines the process taken by this work to translate and interpret the transcripts of the study participants. In the reflexive practitioner's perspective the researcher describes his development journey towards the evaluative criteria for judging the merit of the research by addressing his understanding of knowledge management and compares it with the literature. This study then highlights the dilemma the researcher faced in translating theory into practice and relates this to the organizational knowledge sharing culture.

In the action-researcher's perspective, this study discusses the influence of the philosophical framework with the provision of other authenticating point of views. These three viewpoints relate the research outcomes from the judgments and reflections from a personal life-world to the broader setting of the practitioner's world (Wong, 2003b). Through this action-researcher perspective the researcher, through this study, has come to understand the local situation by thinking reflexively, analyzing evidence, and writing his story of this inquiry (Richardson, 1994, p. 518).

\section{Limitations of the Study}

The limitations of this workshop study pertain to the information gathered through the limited interviews of a small sample size of six participants, from varied cultural backgrounds, and sourced within a single university. The veracity of the data gathered rests solely on the integrity and knowledge of the interviewed participants.

\section{Future Research}

The following issue may be worthy of further investigation. Firstly, compare the effects that political and academic forces within a university to accept or not, new research methodologies within a predominately Western culture and then to compare these same effects with other cultures. Secondly, consider the risks to a University's academic integrity if either new methodologies are or are not accepted. Thirdly, consider the benefits of the skills and processes of reflective practice when taught at the undergraduate level and transferred to the post-graduate stage and early professional life. 


\section{References}

Denzin, N. K., \& Lincoln, Y. S. (Eds.) (1994). Handbook of qualitative research. Thousand Oaks, CA: Sage Publications.

Dewey, J. (1933). How we think. A restatement of the relation of reflective thinking to the educative process (Revised ed.). Boston: D.C. Heath. Retrieved October 23, 2005, from http://www.infed.org/thinkers/et-Dewey.htm

Fitzsimmons, G. (2000). It's people who manage knowledge - not Computers! The British Journal of Administrative Management, 19(March-April), 16.

Friedman, V.J., Lipshitz, R., \& Overmeer, W. (2001). Creating conditions for organizational learning. In M. Dierkes, A. Berthoin Antal, J. Child, \& I. Nonaka, (Eds) Handbook of organizational learning and knowledge (pp. 757-74). Oxford: Oxford University Press.

Glesne, C., \& Peshkin, A. (1992). Becoming qualitative researchers: An introduction. New York: Longman Press.

Habermas, J. (1984). The theory of communicative action, Volume 1. Reason and the rationalisation of society. (T. McCarthy, Trans.). Boston: Beacon Press.

Habermas, J. (1987). The theory of communicative action: Lifeworld and social system. Boston: Beacon Press

Kanter, R. M., (2000). Knowledge workers. Executive Excellence, 17(1), 15-16.

Light, G., \& Cox, R. (2001). Learning and teaching in higher education: The reflective professional. Thousand Oaks, CA: Sage Publications.

Lyotard, F. (1986). The postmodern condition: A report on knowledge. Manchester: Manchester University Press.

McClane, W. E., \& Mento, A. J. (1991). Information systems management in a distributed world: Changes in power, leadership and teams. London: Falmer Press.

Morgan, D. L. (1998). Focus groups as qualitative research. Newbury Park: Sage Press.

Moon, J. (2000). Reflection in learning and professional development. London: Kogan Page Press.

Moustakas, C. (1990). Heuristic research: Design, methodology and applications, London: Sage Publications.

Ngwenyama, K. O., \& Lee, A. S. (1997). Communication richness in electronic mail: critical social theory and the contextuality of meaning. MIS Quarterly, 21(2), 145-168.

Nonaka, I., \& Takeuchi, H. (1995). The knowledge creating company: How Japanese companies create the dynamics of innovation. New York:Oxford University Press.

Peterson, M. W. (2000). The role of institutional research: From improvement to redesign. In J. F. Volkwein (Ed.), What is institutional research all about? (pp. 98-110). Jossey-Bass: Wiley.

Proctor, K. (1993). Tutors professional knowledge of supervision and the implications for supervision practice. In J. Calderhead \& P. Gates (Eds), Conceptualizing reflection in teacher development. London: Falmer Press.

Reason, P. (1999). General medical and complementary practitioners working together: The epistemological demands of collaboration. Journal of Applied Behavioral Science, 35(1), 71-86.

Reason, P., \& Bradbury, H. (2001). Introduction: Inquiry and participation in search of a world worthy of human aspiration. In P. Reason \& H. Bradbury (Eds.), Handbook of action research: Participative inquiry and practice (pp. 1-14). London: Sage Press.

Richardson, L. (1994). Writing: A method of inquiry. In N. Denzin \& Y. Lincoln (Eds), Handbook of qualitative research (pp. 516-522). California: Sage Press. 
Schön, D. A. (1983). The reflective practitioner. Aldershot: Averburt Press.

Schön, D. A. (1987). Educating the reflective practitioner. San Francisco, CA: Jossey Bass Press.

Smyth, J. (1989). Developing and sustaining critical reflection in teacher education, Journal of Teacher Education, 40(2), 2-9.

Standing, C., \& Benson, S. (2000). Organizational culture and knowledge management. Proceedings of the Pacific Asia Conference on Information Systems, Hong Kong City, Hong Kong, pp. 22-28.

Van Manen, M. (1995). Researching lived experience. Canada: Althouse Press University of Western Ontario.

Van Manen, M. (2000). Inquiry: empirical methods. Retrieved September 24, 2005, from http://www.phenomenologyonline.com/

Whitehead, J. (1993). The growth of educational knowledge, creating your own living educational theories. Bournemouth: Hyde Publications.

Whitehead, J (1996).Living educational theories and living contradictions: A response to Mike Newby. Journal of Philosophy of Education, 30(3), 457-461.

Whitehead, J. (1998). Developing research-based professionalism through living educational theories. An address to the Educational Studies Association of Ireland, Trinity College, Dublin. Retrieved October 12, 2002, from http://www.bath.ac.uk/ edsajw/writing.shtml

Whitehead, J. (2002). What counts as evidence in self-studies of teacher education practices? Retrieved October 24, 2005, from http://www.bath.ac.uk/ edsajw/writing.shtml

Wieman, H. N. (1946). The source of human good. Chicago: University of Chicago Press.

Williams, M. C. (2000a). Discussing research writing styles. Proceedings of the World Congress of Action Research, Perth, Australia, pp. 185-197.

Williams, M. C. (2000b). Using heuristic self-study to research information systems education. Proceedings of the International Association of Information Management Conference, Brisbane, Australia, pp. $37-45$.

Williams, M. C. (2001). A self study of teaching reform in a university information systems course: “...it all went wrong...." Retrieved October 2, 2005, from http://www.qualitative-research.net/fqs.htm

Wong, E. S. (2003a). Action research philosophy: The fountain of living research. Perth: Centre of Professional Practitioner Resources Publication.

Wong, E. S. (2003b). Action research: The living thesis. Perth: Centre of Professional Practitioner Resources Publication.

Wong, E. S., \& Williams, M. C. (2002). Reflective practitioner research applied to information systems, reality or illusion? Proceedings of the Third International Web-B Conference, Perth, Australia, pp. 1017.

Yin, R. K. (1994). Case study research design and methods (2nd ed.). Thousand Oaks, CA: Sage Press.

Zimmenman, B. (1999). Complexity science: A route through hard times and uncertainty. Health Forum Journal, 42(2), 42-46. 


\section{Appendix}

\section{Action Research review form}

Please rate your response to the manuscript on the scale below, using the following range of responses. (1=Strongly disagree (S.D.) to $5=$ Strongly agree (S.A.):

\begin{tabular}{|c|c|c|c|c|c|c|}
\hline AR1: & $\begin{array}{l}\text { The extent to which the researcher explicitly ad- } \\
\text { dresses the qualities they believe relevant to their } \\
\text { work and the choices they have made in their work. }\end{array}$ & $\begin{array}{l}1 \\
\square\end{array}$ & $\begin{array}{l}2 \\
\square\end{array}$ & $\begin{array}{l}3 \\
\square\end{array}$ & $\begin{array}{l}4 \\
\square\end{array}$ & $\begin{array}{l}5 \\
\square\end{array}$ \\
\hline AR2: & $\begin{array}{l}\text { The extent to which the quality criteria choices mani- } \\
\text { fest in the finding link with and contribute to the lit- } \\
\text { erature in the field the researcher are qualified to re- } \\
\text { view }\end{array}$ & $\begin{array}{l}1 \\
\square\end{array}$ & $\begin{array}{l}2 \\
\square\end{array}$ & $\begin{array}{l}3 \\
\square\end{array}$ & $\begin{array}{l}4 \\
\square\end{array}$ & \\
\hline AR3: & . & $\begin{array}{l}1 \\
\square\end{array}$ & $\begin{array}{l}2 \\
\square\end{array}$ & $\begin{array}{l}3 \\
\square\end{array}$ & $\begin{array}{l}4 \\
\square\end{array}$ & $\begin{array}{l}5 \\
\square\end{array}$ \\
\hline AR4: & $\begin{array}{l}\text { to which the manuscript exhibits overall } \\
\text { quality. }\end{array}$ & 1 & $\begin{array}{l}2 \\
\square\end{array}$ & $\begin{array}{l}3 \\
\square\end{array}$ & $\begin{array}{l}4 \\
\square\end{array}$ & $\begin{array}{l}5 \\
\square\end{array}$ \\
\hline AR5: & $\begin{array}{l}\text { The extent to which the insights in the manuscript are } \\
\text { significant in content and process. By significant we } \\
\text { mean having meaning and relevance beyond their } \\
\text { immediate context in support of the flourishing of } \\
\text { persons, communities, and the more than human } \\
\text { world. }\end{array}$ & $\begin{array}{l}1 \\
\square\end{array}$ & $\begin{array}{l}2 \\
\square\end{array}$ & $\begin{array}{l}3 \\
\square\end{array}$ & $\begin{array}{l}4 \\
\square\end{array}$ & $\begin{array}{l}5 \\
\square\end{array}$ \\
\hline AR6: & $\begin{array}{l}\text { The extent to which the manuscript helps defines Ac- } \\
\text { tion Research in a way that the researcher wants. }\end{array}$ & $\begin{array}{l}1 \\
\square\end{array}$ & $\begin{array}{l}2 \\
\square\end{array}$ & $\begin{array}{l}3 \\
\square\end{array}$ & $\begin{array}{l}4 \\
\square\end{array}$ & $\begin{array}{l}5 \\
\square\end{array}$ \\
\hline AR7: & $\begin{array}{l}\text { The extent to which the manuscript has an acceptable } \\
\text { "contribution to length" value or ratio. }\end{array}$ & $\begin{array}{l}1 \\
\square\end{array}$ & $\begin{array}{l}2 \\
\square\end{array}$ & $\begin{array}{l}3 \\
\square\end{array}$ & $\begin{array}{l}4 \\
\square\end{array}$ & $\begin{array}{l}5 \\
\square\end{array}$ \\
\hline AR8: & $\begin{array}{l}\text { The extent to which the research process is articu- } \\
\text { lated and clarified }\end{array}$ & $\begin{array}{l}1 \\
\square\end{array}$ & $\begin{array}{l}2 \\
\square\end{array}$ & $\begin{array}{l}3 \\
\square\end{array}$ & $\begin{array}{l}4 \\
\square\end{array}$ & $\begin{array}{l}5 \\
\square\end{array}$ \\
\hline AR9: & $\begin{array}{l}\text { The relevance and significance of the paper for the } \\
\text { world of practice }\end{array}$ & $\begin{array}{l}1 \\
\square\end{array}$ & $\begin{array}{l}2 \\
\square\end{array}$ & $\begin{array}{l}3 \\
\square\end{array}$ & $\begin{array}{l}4 \\
\square\end{array}$ & $\begin{array}{l}5 \\
\square\end{array}$ \\
\hline AR10: & $\begin{array}{l}\text { The extent to which the work has appropriate rele- } \\
\text { vance for second and third person perspectives }\end{array}$ & $\begin{array}{l}1 \\
\square\end{array}$ & $\begin{array}{l}2 \\
\square\end{array}$ & $\begin{array}{l}3 \\
\square\end{array}$ & $\begin{array}{l}4 \\
\square\end{array}$ & $\begin{array}{l}5 \\
\square\end{array}$ \\
\hline
\end{tabular}




\section{Biography}

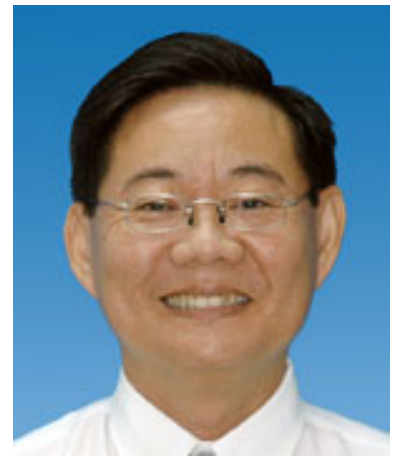

Dr. Edward Sek Wong is an academic staff at Universiti Tunku Abdul Rahman, Malaysia. Prior to joining academe he worked as a Financial Controller, Consultant (IS) at various financial \& banking institutions across Asia and Australia. He has also published eight books. Edward's books are well known in the field of Action Research for adopting an innovative post-modern approach that breaks new ground in the presentation of how an individual might share learning by communicating personal values in professional practice, allowing the author to draw upon heuristic inquiry to provide the intuitive-emotionalartistic-depth that illuminates one's life and one's learning. Further details about him are provided at http://staff.utar.edu.my/wsk 